\title{
Youtube Learning Media as an Effort to Increase Energy Resources Online Learning Outcomes for Class IV Students
}

\section{Diah Retnasari}

SD Negeri Nongkosawit 02

diahretnasari0201@gmail.com

\section{Article History}

received 3/12/2020

revised $17 / 12 / 2020$

accepted 31/12/2020

\begin{abstract}
The purpose of this research is to increase student learning outcomes boldly on energy source material in class IV by using Youtube learning media. The research conducted was Classroom Action Research (CAR) in two cycles. Each cycle consists of planning, action, observation, and reflection. Data collection techniques used were observations, tests, and documentation of teacher and student activities, as well as written tests of student learning outcomes. In the first cycle of students who completed by $36 \%$. In the second cycle of students who completed by $85 \%$. These results indicate that the use of YouTube learning media can increase the learning outcomes of energy source material boldly in fourth grade students at SD Negeri Nongkosawit 02 for the 2019/2020 academic year.
\end{abstract}

Keywords: learning outcomes, energy sources, youtube

\section{Abstrak}

Tujuan dari penelitian ini adalah untuk meningkatkan hasil belajar siswa secara daring pada materi sumber energi di kelas IV dengan menggunakan media pembelajaran Youtube. Penelitian yang dilakukan adalah Penelitian Tindakan Kelas (PTK) sebanyak dua siklus. Masing-masing siklus terdiri dari perencanaan, Tindakan, pengamatan, dan refleksi. Teknik pengumpulan data yang digunakan adalah observasi, tes, dan dokumentasi aktivitas guru dan siswa, serta tes tertulis hasil belajar siswa. Pada siklus I siswa yang tuntas sebesar $36 \%$. Pada siklus II siswa yang tuntas sebesar $85 \%$. Hasil ini menunjukkan bahwa penggunaan media pembelajaran Youtube dapat meningkatkan hasil belajar materi sumber energi secara daring pada siswa kelas IV di SD Negeri Nongkosawit 02 Tahun Pelajaran 2019/2020.

Kata kunci: hasil belajar, sumber energi, youtube 


\section{PENDAHULUAN}

Pada awal tahun 2020, dunia sedang waspada dengan sebuah virus yang disebut dengan corona virus yang menyebabkan penyakit COVID-19. COVID-19 telah menjadi pademi, sehingga pemerintah di bebagai negara telah menerapkan lockdown atau karantina. Pengertian karantina menurut UU Republik Indonesia Nomor 6 tahun 2018 tentang Kekarantinaan Kesehatan adalah pembatasan kegiatan dan/atau pemisahan seseorang yang terpapar penyakit menular sebagaimana ditetapkan dalam peraturan perundang-undangan meskipun belum menunjukkan gejala apapun atau sedang berada dalam masa inkubasi, dan/atau pemisahan peti ke,as, alat aangkut, atau barang apapun yang diduga terkontaminasi dari orang dan/atau barang yang mengandung penyebab penyakit atau sumber bahan kontaminasi lain untuk mencegah kemungkinan penyebaran ke orang dan/atau barang di sekitarnya (UU No 6 tahun 2018).

Pemerintah Indonesia telah menghimbau untuk tetap di dalam rumah dan mengisolasi diri. Pemerintah Indonesia menerapkan aturan PSBB yang merupakan singkatan dari Pembatasan Sosial Berskala Besar yang dibuat dalam rangka Penanganan COVID-19. Hal ini dilakukan dengan harapan virus tidak menyebar lebih luas dan upaya penyembuhan dapat berjalan maksimal. Dalam usaha pembatasan sosial ini pemerintah Indonesia telah membatasi kegiatan diluar rumah seperti kegiatan pendidikan yang telah dilakukan secara online melalui pembelajaran online. Pembelajaran online adalah pembelajaran yang dilakukan melalui jaringan internet. Oleh karena itu, dalam Bahasa Indonesia pembelajaran online diterjemahkan sebagai 'pembelajaran dalam jaringan' atau 'pembelajaran daring' (Belawati, 2020).

Pada pembelajaran online, siswa menjadi kurang aktif dalam menyampaikan aspirasi dan tingkat hasil belajar siswa tidak maksimal sehingga dapat mengakibatkan pembelajaran yang menjenuhkan. Siswa yang mengalami kejenuhan dalam belajar akan memperoleh ketidakmajuan dalam pembelajaran seperti halnya hasil belajar terhadap suatu materi pembelajaran. Selain itu, media pembelajaran yang digunakan guru dalam pembelajan online masih dalam bentuk modul file Word yang dikirimkan kepada siswa melalui Whatsapp Group. Pengertian tentang hasil belajar menurut Bloom dalam Rusmono (2017:8) bahwa hasil belajar merupakan perubahan perilaku yang meliputi tiga ranah, yaitu ranah kognitif, afektif dan psikomotor. Ranah kognitif meliputi tujuan-tujuan belajar yang berhubungan dengan memanggil kembali pengetahuan dan pengembangan kemampuan intelektual dan keterampilan. Ranah afektif meliputi tujuan-tujuan belajar yang menjelaskan perubahan sikap, minat, nilainilai dan pengembangan apresiasi serta penyesuaian. Ranah psikomotor mencakup perubahan perilaku yang menunjukkan bahwa siswa telah mempelajari keterampilan manipulatif fisik tertentu. Oleh karena itu, diperlukan strategi yang tepat untuk meningkatkan hasil belajar tematik khususnya pada muatan pelajaran IImu Pengetahuan Alam (IPA) melalui media pembelajaran youtube yang disampaikan oleh guru kepada siswa secara daring (dalam jaringan). Selain itu penggunaan model pembelajaran PBL juga dapat digunakan untuk meningkatkan hasil belajar siswa. Syahroni Ejin (2016) menyatakan bahwa Problem Based Learning (PBL) adalah model pembelajaran dimana siswa dihadapkan pada masalah kehidupan nyata (kontekstual) dari lingkungan sehingga dapat meningkatkan kemampuan pemahaman konsep dan berpikir kritis siswa. Menurut Rahmadani dan Anugraheni (2017) menyatakan bahwa PBL menekankan pada aktivitas pemecahan masalah dalam pembelajaran. Melalui pendekatan PBL siswa belajar melalui aktivitas pemecahan masalah yang dapat mengasah keterampilan berpikir siswa. Problem Based Learning pembelajaran yang menggunakan masalah dunia nyata sebagai suatu konteks bagi peserta didik untuk belajar tentang cara berpikir kritis dan keterampilan pemecahan masalah, serta untuk memperoleh pengetahuan dan konsep yang esensial dari materi pelajaran (Yunin Nurun Nafiah dan Wardan Suyanto, 2014). 
Sintak model PBL menurut Arends (2012) sebagai berikut: 1) orientasi peserta didik pada masalah, 2) mengorganisasikan peserta didik untuk belajar, 3) membimbing penyelidikan individu maupun kelompok, 4) mengembangkan dan menyajikan hasil karya, 5) menganalisis dan mengevaluasi proses pemecahan masalah.

Sanjaya (dalam Wulandari, 2012:2), menyebutkan bahwa keunggulan PBL antara lain: 1) PBL merupakan teknik yang cukup bagus untuk lebih memahami pelajaran, 2) PBL dapat menantang kemampuan siswa serta memberikan kepuasan untuk menemukan pengetahuan baru bagi siswa, 3) PBL dapat meningkatkan aktivitas pembelajaran, 4) melalui PBL bisa memperlihatkan kepada siswa setiap mata pelajaran (matematika, IPA, dan lain sebagainya), pada dasarnya merupakan cara berfikir, dan sesuatu yang harus dimengerti oleh siswa, bukan hanya sekedar belajar dari guru atau buku-buku saja, 5) PBL dianggap PBL dianggap lebih menyenangkan dan disukai siswa, 6) PBL dapat mengem-bangkan kemampuan berpikir kritis, 7) PBL dapat memberikan kesempatan kepada siswa untuk mengaplikasikan pengetahuan yang mereka milik dalam dunia nyata, 8) PBL dapat mengembangkan minat siswa untuk belajar secara terus-menerus sekalipun belajar pada pendidikan formal telah berakhir.Model pembelajaranPBL mempunyai banyak keunggulan tetapi juga memiliki kelemahan.Menurut Sanjaya dalam Wulandari (2012:2), kelemahan model PBL antara lain: 1) siswa tidak mempunyai minat atau tidak mempunyai kepercayaan bahwa masalah yang dipelajari sulit untuk dipecahkan, maka mereka akan merasa raguuntuk mencoba, 2) keberhasilan model pembelajaran PBL membutuhkan cukup waktu untuk persiapan, 3) tanpa pemahaman mengapa mereka berusaha untuk memecahkan masalah yang sedang dipelajari, maka mereka tidak akan belajar apa yang ingin mereka pelajari.

Dalam penelitian ini ditujukan untuk meningkatkan hasil belajar siswa kelas IV SD Negeri Nongkosawit 02 Kecamatan Gunungpati Kota Semarang Tahun Ajaran 2019/2020 dengan menggunakan media pembelajaran Youtube.

\section{METODE}

Penelitian ini dilaksanakan di kelas IV SD Negeri Nongkosawit 02 Kecamatan Gunungpati Kota Semarang. Alamat: Randusari RT 06 RW 02, Kelurahan Nongkosawit, Kecamatan Gunungpati, Kota Semarang. Model penelitian yang digunakan ini adalah Penelitian Tindakan Kelas (PTK) dengan model Kurt Lewin yang dilaksanakan dalam dua siklus. Masing-masing siklus terdiri dari perencanaan, tindakan, pengamatan, dan refleksi (Sukayati: 2008). Teknik pengumpulan data yang digunakan adalah observasi, tes dan dokumentasi. Dalam hal ini observasi dilakukan dengan melihat langsung kondisi di lapangan yaitu pada saat siswa melaksakan pembelajaran jarak jauh sistem daring. Pengamatan dilakukan di rumah siswa kelas IV SD Negeri Nongkosawit 02 yang dilaksanakan pada bulan April 2020. Instrumen tes di berikan pada setiap siklus. Tes dilaksanakan pada tahap siklus I dan II dengan tujuan untuk mengumpulkan data tentang kemampuan hasil belajar siswa terhadap materi sumber energi.

\section{HASIL DAN PEMBAHASAN}

Berdasarkan pelaksanaan tindakan selama dua siklus yang dilakukan sebanyak 2 kali pertemuan, diperoleh data bahwa hasil belajar siswa mengalami peningkatan. Peningkatan hasil belajar diketahui dengan menggunakan media pembelajaran youtube. Hasil observasi terhadap penerapan media pembelajaran youtube dapat dilihat pada tabel berikut 
SHEs: Conference Series 3 (4) (2020) $53-58$

Tabel 1. Persentase Ketuntasan Hasil Belajar Siklus I dan II

\begin{tabular}{cccc}
\multicolumn{2}{c}{ KETUNTASAN } & \multicolumn{2}{c}{ KETIDAKTUNTASAN } \\
\hline Siklus I & Siklus II & Siklus I & Siklus II \\
\hline $36 \%$ & $85 \%$ & $64 \%$ & $15 \%$
\end{tabular}

Berdasarkan tabel di atas persentase ketuntasan hasil belajar materi sumber energi dengan menggunakan media youtube pada siklus I masih $36 \%$, sedangkan pada siklus II mencapai 85\%. Dari observasi hasil belajar materi sumber energi dengan menggunakan media youtube mengalami peningkatan dari siklus I ke siklus II sebesar $49 \%$. Peningkatan hasil belajar materi sumber energi dengan menggunakan media youtube pada siklus I dan II sebagai berikut.

Tabel 2 Pencapaian Hasil Evaluasi Siklus 1 dan Siklus II

\begin{tabular}{clcc}
\multirow{2}{*}{ NO } & \multicolumn{1}{c}{ PENCAPAIAN } & Siklus I & HASIL \\
\cline { 2 - 4 } & & 70 & 70 \\
\hline 1 & Nilai KKM & 590 & 970 \\
2 & Jumlah Nilai & 70 & 100 \\
3 & Nilai Tertinggi & 30 & 50 \\
4 & Nilai Terendah & 11 & 13 \\
5 & Jumlah Siswa Hadir & 4 & 11 \\
6 & Jumlah Siswa Tuntas & 7 & 2 \\
7 & Jumlah Siswa Tidak Tuntas & $36 \%$ & $85 \%$ \\
8 & Persentase Ketuntasan & $64 \%$ & $15 \%$ \\
9 & Persentase Ketidaktuntasan & & \\
\hline
\end{tabular}

Berdasarkan penelitian yang sudah dilaksanakan, diketahui bahwa hasil belajar materi sumber energi dengan menggunakan media youtube mengalami peningkatan. Rata-rata nilai siswa meningkat dari siklus I sebesar 36\% menjadi $85 \%$ pada siklus II. Berdasarkan data tersebut, diketahui bahwa siswa yang telah mencapai KKM pada siklus I sebanyak 4 siswa dari jumlah siswa yang mengikuti pembelajaran daring melalui Zoom Meeting. Pada siklus II terjadi peningkatan mencapai $85 \%$ yang terdiri dari 11 siswa yang telah mencapai KKM. Pencapaian hasil belajar klasikal pada siklus II sudah mencapai indicator keberhasilan karena siswa mengalami ketuntasan belajar individual $\geq 70$.

Dari dua siklus yang sudah dilaksanakan selama dua pertemuan, maka dapat dipastikan bahwa penggunaan media pembelajaran Youtube dapat meningkatkan hasil belajar siswa pada materi sumber energi secara daring di kelas IV SD Negeri Nongkosawit 02.

Hasil penelitian ini relevan dengan penelitian sebelumnya yang telah dilakukan oleh Kholifah, Siti dkk. (2018) yang berjudul Penggunaan Media Youtube Untuk Meningkatkan Hasil Belajar Siswa Pokok Bahasan Sistem Pencernaan Makanan Pada Manusia Kelas VIII di MTs SA Miftahus Saadah Sukorambi Jember Tahun Pelajaran 2017/2018. Pada penelitian tersebut menyebutkan bahwa penggunaan media Youtube terbukti dapat meningkatkan hasil belajar biologi siswa pada pokok bahasan sistem pencernaan makanan pada manusia di kelas VIII MTs SA Miftahus Saadah Sukorambi Jember. Hal ini ditunjukkan dengan adanya peningkatan persentase rata - rata hasil belajar siswa pada siklus I yaitu 78,85 termasuk dalam kategori cukup dengan persentase klasikal sebesar $75 \%$ sedangkan pada pelaksanaan siklus II diketahui hasil belajar rata - rata siswa 86,65 kategori baik dengan persentase klasikal sebesar $85 \%$. Penelitian serupa yang dilaksanakan Pambudi, Rilo dkk. (2018) yang berjudul 
Pengaruh Media Video Youtube Terhadap Prestasi Belajar Matematika Pada Siswa Kelas X SMK Negeri 2 Sukoharjo Tahun Ajaran 2017/2018 penelitian I I menyatakan bahwa kelas yang menggunakan media pembelajaran video youtube memiliki prestasi belajar matematika yang lebih baik dibandingkan kelas yang menggunakan media pembelajaran papan tulis pada siswa kelas X SMK Negeri 2 Sukoharjo Tahun Pelajaran 2017/2018.

\section{SIMPULAN}

Berdasarkan hasil penelitian dan pembahasan dapat disimpulkan bahwa penggunaan media pembelajaran Youtube pada materi sumber energi dapat meningkatkan hasil belajar siswa kelas IV SD Negeri Nongkosawit 02 Kecamatan Gunungpati Kota Semarang tahun pelajaran 2019/2020. Hal ini terlihat dari peningkatan hasil belajar siswa dari setiap siklusnya dilihat dari nilai rata rata kelas dan kriteria ketuntasannya. Berdasarkan hasil penelitian dan kesimpulan, maka disarankan kepada guru bahwa penggunaan media pembelajaran Youtube dapat digunakan sebagai alternatif dalam pemecahan masalah pembelajaran daring pada siswa dimasa pandemi seperti sekarang ini. Penggunaan penggunaan media pembelajaran Youtube juga dapat dikembangkan pada muatan pelajaran lainnya sebagai rujukan pada penelitian selanjutnya.

\section{DAFTAR PUSTAKA}

Arends, R.I. (2012). Learning To Teach. New York: McGraw-Hill Companies, Inc.

Belawati, Tian. (2020). Pembelajaran Online (Edisi Kedua). Banten: Universitas Terbuka.

Ejin, Syahroni. (2016). Pengaruh Model Problem Based Learning (PBL) terhadap Pemahaman Konsep dan Keterampilan Berpikir Kritis Siswa Kelas IV SDN Jambu Hilir Baluti 2 Pada Mata Pelajaran IImu Pengetahuan IImu Pengetahuan Alam. Jurnal Pendidikan, 1(1), 65 - $71 . \quad$ DOI: https://doi.org/10.26740/jp.v1n1.p66-72

Kholifah, Siti, Siti Roudlotul Hikamah, \& Haning Hasbiyati. (2018). Penggunaan Media Youtube Untuk Meningkatkan Hasil Belajar Siswa Pokok Bahasan Sistem Pencernaan Makanan Pada Manusia Kelas VIII Di MTs SA Miftahus Saadah Sukorambi Jember Tahun Pelajaran 2017/2018. Jurnal Bioshell. http://ejurnal.uij.ac.id/index.php/BIO/article/view/358

Nafiah, Y. N., \& Suyanto, W. (2014). Penerapan model problem based learning untuk meningkatkan keterampilan berpikir kritis dan hasil belajar siswa. Jurnal Pendidikan Vokasi, 4(1), 125 - 143. DOI: http://dx.doi.org/10.21831/jpv.v4i1.2540

Pambudi, Rilo, Afif Afghohani, \& Isna Farahsanti. (2018). Pengaruh Media Video Youtube Terhadap Prestasi Belajar Matematika Pada Siswa Kelas X SMK Negeri 2 Sukoharjo Tahun Ajaran 2017/2018. Jurnal Pendidikan Univet Bantara. http://journal.univetbantara.ac.id/index.php/JP/article/view/345

Rahmadani, N., \& Anugraheni, I. (2017). Peningkatan aktivitas belajar matematika melalui pendekatan problem based learning bagi siswa kelas 4 SD. Jurnal $\begin{array}{lllll}\text { Scholaria, } & 7(3), & 241 & - & 250 .\end{array}$ https://doi.org/10.24246/j.scholaria.2017.v7.i3.p241-250

Republik Indonesia. (2018). Undang-Undang RI Nomor 6, Tahun 2018, tentang Kekarantinaan Kesehatan.

Rusmono. (2017). Strategi Pembelajaran Dengan Problem Based Learning Itu Perlu (Edisi Kedua). Bogor: Ghalia Indonesia.

Sukayati. 2008. Penelitian Tindakan Kelas. Yogyakarta: Dirjen Dikti. 
SHEs: Conference Series 3 (4) (2020) $53-58$

Wulandari, Eni. (2012). Penerapan Model PBL (Problem Based Learning) pada Pembelajaran IPA Siswa Kelas V SD. Jurnal FKIP-Universitas Sebelas Maret. 